\title{
Effect of seed treatment with insecticides on the control of Spodoptera frugiperda (J. E. Smith) (Lepidoptera: Noctuidae) in soybean
}

\section{Efeito do tratamento de sementes com inseticidas no controle de Spodoptera frugiperda (J. E. Smith) (Lepidoptera: Noctuidae) na cultura da soja}

\author{
Yago Barros Triboni ${ }^{*}$ (D), Luciano Del Bem Junior ${ }^{1}$ (D), Carlos Gilberto Raetano ${ }^{\text {(D), }}$ \\ Matheus Mereb Negrisoli ${ }^{1}$
}

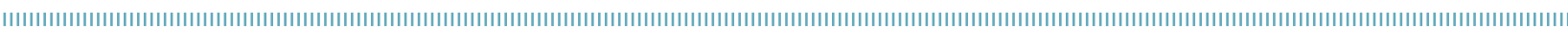

\begin{abstract}
Fall armyworm is one of the main insect pests in Brazil. Thus, the present work aimed to evaluate the seed treatment effect on the control of Spodoptera frugiperda in initial infestations of soybean crops. The experimental design was completely randomized with four replicates of six insecticide treatments applied through seed treatment: imidacloprid plus thiodicarb at the dose of 52.5 plus $105 \mathrm{~g}$ a.i. (active ingredient) $100 \mathrm{~kg}^{-1}$ of

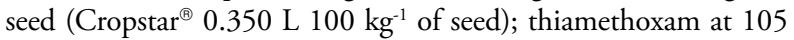
g a.i. $100 \mathrm{~kg}^{-1}$ of seed (Cruiser $350 \mathrm{FS}^{\circledR} 0.3 \mathrm{~L} 100 \mathrm{~kg}^{-1}$ of seed); chlorantraniliprole at $62.5 \mathrm{~g}$ a.i. $100 \mathrm{~kg}^{-1}$ of seed (Dermacor ${ }^{\circledR}$

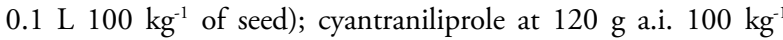

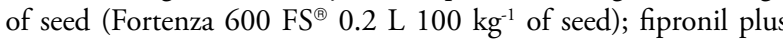
pyraclostrobin and thiophanate-methyl $50+5+45$ g a.i. $100 \mathrm{~kg}^{-1}$

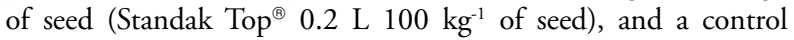
treatment. The experiment was carried out in a greenhouse. Diamide insecticides (chlorantraniliprole and cyantraniliprole) presented the best results among all treatments, with lower consumption of the treated leaves by the caterpillars and greater control efficacy of this insect. We verified that seed treatment is a viable alternative for controlling $S$. frugiperda at the beginning of crop development, when the caterpillar presents the behavior of cutting the seedlings and/or the consumption of leaf area, causing a reduction in the plant population and a consequent yield loss.
\end{abstract}

KEYWORDS: chemical control; diamide; fall armyworm; mortality.
RESUMO: A lagarta-do-cartucho é um dos principais insetos-praga no Brasil. Assim, o presente trabalho teve por objetivo avaliar o efeito do tratamento de sementes no controle de Spodoptera frugiperda nas infestaçóes iniciais da cultura da soja. O delineamento experimental foi inteiramente casualizado, com quatro amostras replicadas de seis tratamentos inseticidas aplicados via tratamento de sementes: imidacloprida mais tiodicarbe na dose de 52,5 mais $105 \mathrm{~g}$ i.a. (ingrediente ativo) $100 \mathrm{~kg}^{-1}$ de sementes (Cropstar ${ }^{\circledR} 0,350 \mathrm{~L} 100 \mathrm{~kg}^{-1}$ de sementes); tiametoxam a $105 \mathrm{~g}$ i.a. 100 $\mathrm{kg}^{-1}$ de sementes (Cruiser $350 \mathrm{FS}^{\circledR}$ 0,3 L $100 \mathrm{~kg}^{-1}$ de sementes); clorantraniliprole a 62,5 gi.a. $100 \mathrm{~kg}^{-1}$ de sementes (Dermacor ${ }^{\circledR} 0,1 \mathrm{~L} 100 \mathrm{~kg}^{-1}$ de sementes); ciantraniliprole a $120 \mathrm{~g}$ i.a. $100 \mathrm{~kg}^{-1}$ de sementes (Fortenza

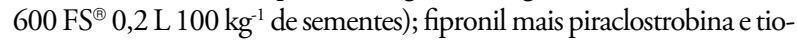
fanato-metílico $50+5+45$ g i.a. $100 \mathrm{~kg}^{-1}$ de sementes (Standak Top ${ }^{\circledR}$

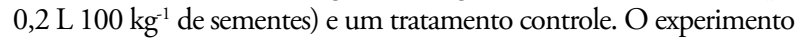
foi conduzido em uma vegetaçáo. Dentre todos os tratamentos, os inseticidas do grupo químico das diamidas (clorantraniliprole e ciantraniliprole) apresentaram os melhores resultados, com consumo inferior pelas lagartas das folhas tratadas e maior eficiência de controle deste inseto. Foi constatado que o tratamento de sementes é uma alternativa viável para o controle de $S$. frugiperda no início do desenvolvimento da cultura, quando a lagarta apresenta o comportamento de cortar as plântulas e/ou consumir área foliar, ocasionando uma reduçáo da populaçáo de plantas e uma consequente perda de produtividade.

PALAVRAS-CHAVE: controle químico; diamidas; lagarta-do-cartucho; mortalidade. 


\section{INTRODUCTION}

Soybean cultivation is responsible for several changes in the Brazilian agriculture and agribusiness since the mid-1970s, and soybeans are the main agricultural product for export (ESPÍNDOLA, 2015). Currently, soybeans are cultivated in the most unlike geographical regions of the country, and the states of Mato Grosso, Paraná, Rio Grande do Sul and Goiás are considered the largest national producers. During the last crop season, Brazil cultivated approximately 33 million hectares, producing the equivalent to 114 million tons and remaining the second largest producer and exporter in the world, only behind the United States of America (CONAB, 2018).

Crop cultivation intensification in agricultural areas, climate change, development of resistance mechanisms in phytopathogenic agents, introduction of exotic pests, and indiscriminate use of pesticides have led to an imbalance in agroecosystems, making the rational use of several management strategies necessary in food production (DEL BEM JÚNIOR, 2017).

Planting crops with different phenologies, such as corn and cotton (grown in the summer), and cover plants, such as millet (grown in the period between harvests), close to one another facilitates the movement of Spodoptera frugiperda among plant species (NAGOSHI, 2009). This may be the cause of the more frequent occurrence of this pest in crops where it was previously considered sporadic or secondary (BARROS et al., 2010). In soybean, S. frugiperda attacks are more frequent among seedlings due to the presence of caterpillars in the straw, with higher occurrence in fields of the Cerrado biome, which is usually associated with periods or years of low rainfall.

Therefore, seed treatment with insecticide is recommended for producers who adopt good agricultural practices and as part of integrated pest management, since it ensures the rational use of products, reduction of environmental impact, and maintenance of the population of natural enemies at adequate levels. It also regulates the population fluctuations of the most important pests. According to BALARDIN et al. (2011), this practice is efficient since it assures an adequate population of plants when edaphoclimatic conditions during sowing are unfavorable to germination and rapid emergence. DHINGRA (1985) affirms that seed treatment is an important process and the first effective step for plant protection. The absence of this initial form of protection may have a direct impact on crop yield, with a significant reduction in farmer profitability (BUZZERIO, 2010).

In Brazil, there are several chemical groups used in seed treatment to control different soybean pests, such as methylcarbamate, pyrazole, abamectin, and diamides. These insecticides are found in the market independently or in association with other products that may or may not influence caterpillars (CHIESA et al., 2016). According to the author of such study, by analyzing each active ingredient in isolation, it is possible to evaluate the contribution in terms of efficacy of each one for use as a background to elaborate the most efficient strategies for pest management and control.

Therefore, the goal of this study was to evaluate the seed treatment effect with insecticides on the control of $S$. frugiperda in initial infestations of soybean crops under environmentally controlled conditions.

\section{MATERIALS AND METHODS}

\section{Experimental characterization}

The experiment was carried out in a greenhouse at the Crop Protection Department, School of Agronomical Sciences, Universidade Estadual Paulista "Júlio de Mesquita Filho"(Unesp), Botucatu, São Paulo, Brazil. The soybean seeds were sown on February 10, 2017, using five seeds of the BMX Turbo RR cultivar (germination estimated at $80 \%$ ) per pot and maintaining three plants per pot after thinning. For this purpose, 24 plastic pots with a capacity of $1.0 \mathrm{~kg}$ were filled with Tropstrato ${ }^{\circledast}$ substrate composed of pine bark, peat, vermiculite, simple superphosphate, and potassium nitrate.

For the seed treatment, 2-L plastic bags were used, in which water and insecticides were added for each treatment at the correct doses for treating $0.5 \mathrm{~kg}$ of seed of the BMX Turbo RR cultivar. The seeds were then transferred to the plastic bags and vigorously agitated until complete coverage with the respective products, according to the methodology proposed by CUNHA et al. (2015).

The experimental design was completely randomized with six treatments and four replicates, and each plot consisted of one pot. The following treatments were used: $\mathrm{T} 1$ - imidacloprid plus thiodicarb at $52.5+105 \mathrm{~g}$ a.i. $100 \mathrm{~kg}^{-1}$ of seed (Cropstar ${ }^{\oplus}$ at $0.350 \mathrm{~L} 100 \mathrm{~kg}^{-1}$ of seed); T2 - thiamethoxam at $105 \mathrm{~g}$ a.i. $100 \mathrm{~kg}^{-1}$ of seed (Cruiser $350 \mathrm{FS}^{\circledR}$ at $0.3{\mathrm{~L} 100 \mathrm{~kg}^{-1}}^{-1}$ of seed); T3 - chlorantraniliprole at $62.5 \mathrm{~g}$ a.i. $100 \mathrm{~kg}^{-1}$ of seed

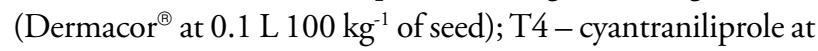
$120 \mathrm{~g}$ a.i. $100 \mathrm{~kg}^{-1}$ of seed (Fortenza $600 \mathrm{FS}^{\oplus}$ at $0.2 \mathrm{~L} 100 \mathrm{~kg}^{-1}$ of seed); T5 - fipronil plus pyraclostrobin plus thiophanatemethyl at $50+5+45$ g a.i. $100 \mathrm{~kg}^{-1}$ of seed (Standak Top ${ }^{\circledast}$ at $0.2 \mathrm{~L} 100 \mathrm{~kg}^{-1}$ of seed); T6 - control treatment without seed treatment according to Table 1.

\section{Caterpillar infestation}

Third-instar $S$. frugiperda larvae were acquired from the Promip ${ }^{\circledR}$ biofactory, located in Engenheiro Coelho city, São Paulo, and transported to the laboratory in $300 \mathrm{~mL}$ plastic cups containing 100 larvae with a specific diet developed by the company laboratory and with cooled gel plates for appropriate temperature maintenance. 
The release of third-instar $S$. frugiperda larvae occurred ten days after seedling emergence by applying one caterpillar per plant for a total of three caterpillars per pot. These caterpillars were transferred with a brush to the soybean leaflets, and the pots were then covered with voile fabric (anti-fly fabric). The evaluations were conducted at 24,48 , and 72 hours after caterpillar transference, all at the same time, by measuring the consumed leaf area and the mortality of the caterpillars in each treatment.

On the last day of the leaf area consumption evaluation, all the leaves that showed visible damage were collected and separated according to the treatment and replicate. The damaged leaf area was determined with the digital image analysis software from the American Phytopathological Society (APS), the Assess Image Analysis Software for Plant Disease Quantification, version 2.0 (Lamari, Department of Plant Science, University of Manitoba, Winnipeg, Manitoba, Canada). Data regarding the number of dead caterpillars were $(x+1)^{1 / 2}$ transformed and subjected to analysis of variance according to the $\mathrm{F}$ test using the Sisvar ${ }^{\oplus}$ program, version 5.6 (FERREIRA, 2011). The mean values were compared by Tukey's test $(\mathrm{p}<0.05)$.

\section{RESULTS AND DISCUSSION}

Data obtained in this study show that the insecticidal treatments thiamethoxam (T2), fipronil plus pyraclostrobin and thiophanate-methyl (T5), and imidacloprid plus thiodicarb (T1) did not differ statistically from the control (T6). It indicates the low efficiency of these insecticides in controlling S. frugiperda (Fig. 1). These results corroborate those obtained by BUENO et al. (2010), who observed low efficiency in the control of third-and fourth-instar $S$. frugiperda larvae with the insecticide thiodicarb at $600 \mathrm{~g}$ a.i. (less than $40 \%$ ).

The products that showed low efficiency are not officially registered to control this insect pest, but they are used in mixtures intended for not only the seed treatment according to the on-farm method, but also the industrial seed treatment (IST).

The chlorantraniliprole (T3) and cyantraniliprole (T4) insecticidal treatments differed statistically from the other treatments, presenting smaller leaf areas consumed by the caterpillars of 1.75 and $1.87 \%$, respectively. These treatments are, therefore, important management tools for decreasing leaf area losses that consequently reduce crop yield (Figs. 1 and 2). The anthranilic diamide insecticide group, to which T3 and T 4 belong, has high insecticidal activity and low toxicity to mammals as main characteristics (LAHM et al., 2007). These insecticides bind to ryanodine receptors of the insect in muscle cells, promoting the uncontrolled exit of calcium from the sarcoplasmic reticulum caused by channel opening, thereby resulting in muscle paralysis and insect death (CORDOVA et al., 2006).

In terms of caterpillar mortality, the cyantraniliprole (T4) insecticidal treatment differed from the other treatments,

Table 1. Characterization of the insecticides and their respective dosages used in the seed treatment.

\begin{tabular}{|c|c|c|c|}
\hline Treatment & Trade name & Active ingredient & Dosage (mL $100 \mathrm{~kg}^{-1}$ of seed) \\
\hline 1 & Cropstar $^{\circledR}$ & Imidacloprid + Thiodicarb & 500 \\
\hline 2 & Cruiser $^{\circledR}$ & Thiamethoxam & 200 \\
\hline 3 & Dermacor $^{\circledast}$ & Chlorantraniliprole & 100 \\
\hline 4 & Fortenza $^{\circledR}$ & Cyantraniliprole & 200 \\
\hline 5 & Standak Top ${ }^{\circledR}$ & Fipronil + Pyraclostrobin + Thiophanate-Methyl & 200 \\
\hline 6 & Control & - & - \\
\hline
\end{tabular}

A

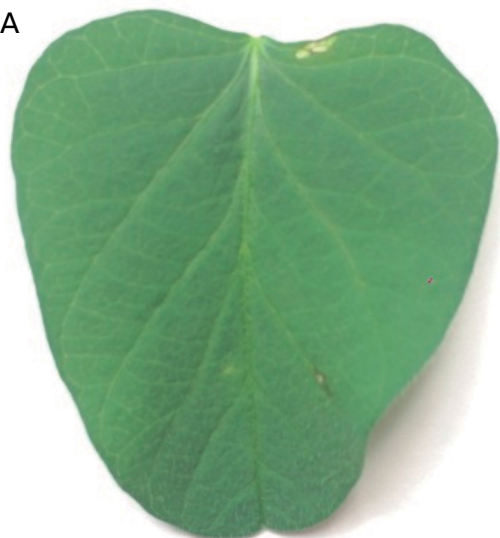

\section{B}

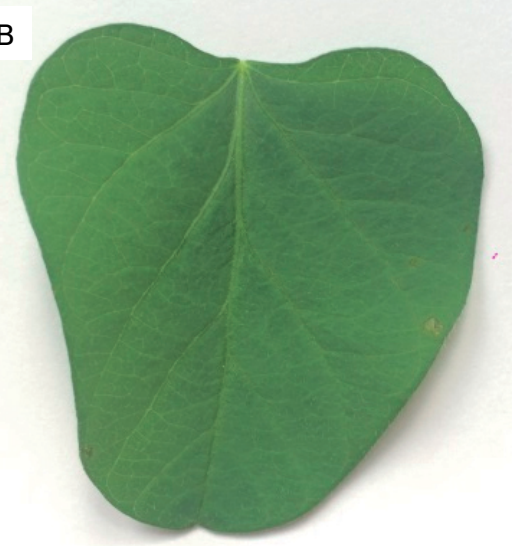

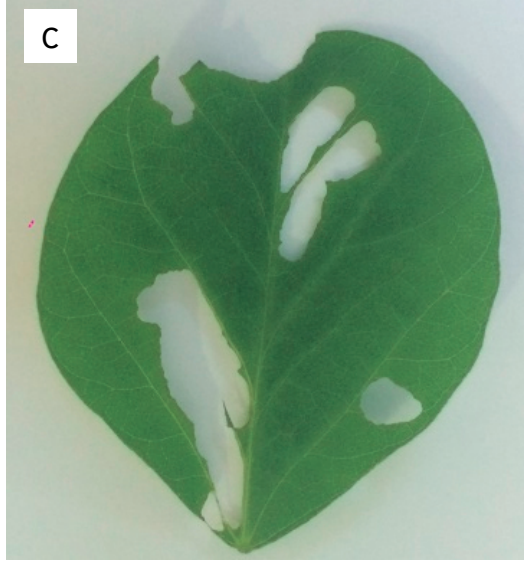

Figure 1. Soybean leaflet after seed treatment with chlorantraniliprole (A) and cyantraniliprole (B) and control without treatment (C). 
with higher control efficiency in the first 24 hours after the release of caterpillars onto the plants $(90.91 \%)$. In contrast, the chlorantraniliprole (T3) and imidacloprid plus thiodicarb (T1) insecticidal treatments did not differ statistically from T4, but they showed lower control efficiency on the first day of evaluation, with efficacy values of 72.73 and $54.55 \%$, respectively (Table 2). Thiamethoxam (T2) showed the lowest efficiency $(9.09 \%)$, which is not different from the untreated control. KUSS et al. (2016), using second instar Helicoverpa armigera larvae that received leaves harvested 24 hours after spraying, observed better control efficiency associated with the chlorantraniliprole and flubendiamide (diamides) insecticidal treatments, with $100 \%$ accumulated insect mortality three days after caterpillar exposure. Thus, the capacity

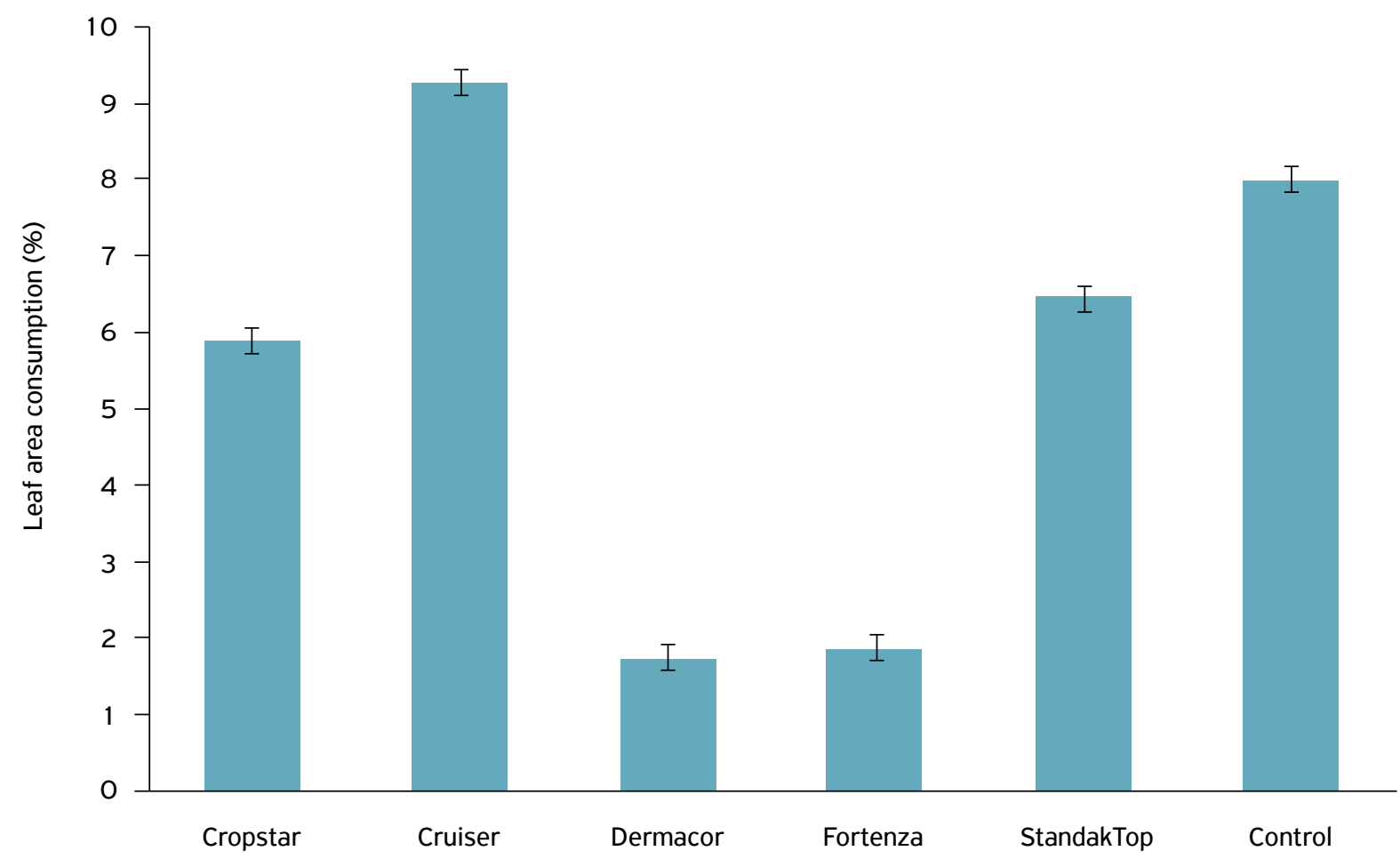

Treatments

Figure 2. Effect of seed treatment with insecticides on the percentage of leaf area consumed by third instar Spodoptera frugiperda larvae (Coefficient of Variation in \%: 13.73; Least significant difference: 0.78 ).

Table 2. Mortality and control efficiency (\%) of insecticides applied in the seed treatment against Spodoptera frugiperda one, two, and three days after caterpillar release among soybean plants.

\begin{tabular}{|c|c|c|c|c|c|c|c|}
\hline \multirow{3}{*}{ Treatment } & \multirow{3}{*}{ Trade name } & \multicolumn{6}{|c|}{ Time after release of caterpillars (hours) } \\
\hline & & \multicolumn{2}{|c|}{24} & \multicolumn{2}{|c|}{48} & \multicolumn{2}{|c|}{72} \\
\hline & & $M^{1}$ & EF (\%) & $M^{1}$ & EF (\%) & $M^{1}$ & EF (\%) \\
\hline $\mathrm{T} 1$ & Cropstar & $1,75 a b^{*}$ & 54,55 & $2,00 \mathrm{a}$ & 60,00 & $2,00 \mathrm{a}$ & 60,00 \\
\hline $\mathrm{T} 2$ & Cruiser & $0,50 \mathrm{~cd}$ & 9,09 & $0,75 \mathrm{~b}$ & 10,00 & $0,75 b$ & 10,00 \\
\hline T3 & Dermacor & $2,25 a b$ & 72,73 & $3,00 \mathrm{a}$ & 100,00 & $3,00 \mathrm{a}$ & 100,00 \\
\hline T4 & Fortenza & $2,75 \mathrm{a}$ & 90,91 & $3,00 \mathrm{a}$ & 100,00 & $3,00 \mathrm{a}$ & 100,00 \\
\hline T5 & Standak Top & $1,50 \mathrm{bc}$ & 45,45 & $2,00 \mathrm{a}$ & 60,00 & $2,50 \mathrm{a}$ & 80,00 \\
\hline T6 & Control & $0,25 d$ & - & $0,50 \mathrm{~b}$ & - & $0,50 \mathrm{~b}$ & - \\
\hline CV (\%) & & 10,64 & - & 10,65 & - & 9,98 & - \\
\hline F value & & $15,90^{* *}$ & - & $14,49^{* *}$ & - & $17,01^{* *}$ & - \\
\hline
\end{tabular}

*Means followed by the same letters in a column do not differ according to Tukey's test ( $p<0.05)$; $\mathrm{M}^{1}$ : caterpillar mortality; $\mathrm{EF}(\%)$ : treatment efficiency calculated according to Abbott formula (ABBOTT, 1925); "*significant values according to the $F$ test. 
for diamide translocation allowed a greater contribution of the insecticide to the apical leaves from the spray treatment intercepted by the other parts of the plant, contributing to better control of second instar larvae 72 hours after spraying (CAMERON et al., 2015).

In the second evaluation, 48 hours after caterpillar release, the treatments with insecticides belonging to the diamide chemical group (T3 and T4) reached $100 \%$ caterpillar control. The imidacloprid and thiodicarb (T1) and fipronil plus pyraclostrobin and thiophanate-methyl (T5) treatments did not differ statistically from those that obtained greater control, but they presented a $60 \%$ efficacy compared to that of the control. The insecticide thiamethoxam showed the poorest increase in mortality of these insects over time, from $9.09 \%$ on the first day to $10 \%$ on the second (Table 2).

As a result of poisoning by diamides, the insect undergoes the sudden cessation of feeding, lethargy, paralysis and finally death (HANNIG, 2009). This insecticide presents high activity against Lepidopteran species, as well as species of Coleoptera, Diptera and Hemiptera (KUHAR et al., 2008; TEMPLE et al., 2009). LAI; SU (2011) reported that the greatest mortality of Spodoptera exigua caused by chlorantraniliprole occurred within the first four days of exposure, because it is a slow-acting insecticide that acts primarily via ingestion. The delayed mortality observed for diamides (1-4 days) can be attributed, at least in part, to the fact that diamides need to be ingested to initiate their insecticidal activity. However, diamides act quickly on the target pest, and less than 24 hours of feed disruption, which contrasts with what occurs following the application of other newly developed insecticides (HANNIG et al., 2009).

In the third evaluation, 72 hours after exposure, the insecticidal treatments maintained their control efficiency values in all cases except for T5 (fipronil + pyraclostrobin + thiophanatemethyl), which showed a $20 \%$ increase over the final product efficiency. Thus, the insecticidal activity against the caterpillars occurred, for the most part, within 48 hours (Table 2).
Therefore, for treatments that did not attain 100\% mortality, the alternative to complement the insecticidal effect on the insect targets is to consider the time interval between crop seasons (fallow). This consideration combined with the chemical control performed by the seed treatment may reduce the initial attack of pests on subsequent crops (PEDIGO, 2002).

To improve $S$. frugiperda management in early soybean planting, seed treatment with insecticides of the diamide chemical group should be considered as a control option. Therefore, seed treatment may not only be used to control older instars of $S$. frugiperda caterpillars, but may also be used as a technique that has a relatively low impact on natural enemies, providing greater balance to the agroecosystem.

\section{CONCLUSIONS}

Treatment of soybean seeds with insecticides of the diamide chemical group was shown to be the best option for controlling Spodoptera frugiperda, significantly reducing the consumed leaf area and quickly increasing caterpillar mortality.

The application of the insecticide thiamethoxam $\left(\mathrm{Cruiser}^{\circledR}\right)$ through seed treatment showed the lowest control efficiency of Spodoptera frugiperda during the evaluation period in soybean plants.

\section{ACKNOWLEDGMENTS}

The authors thank the Crop Protection Department, School of Agricultural Sciences of Unesp, Botucatu Campus, and the Seed Care Institute Latin America for their support in the execution of this study. This study was partly financed by the Coordenação de Aperfeiçoamento de Pessoal de Nivel Superior (CAPES), Brazil, Finance Code 001.

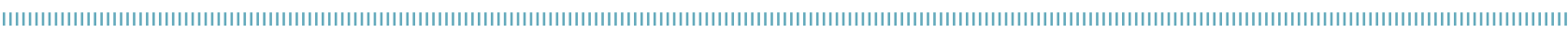
REFERENCES

ABBOTT, W.S. A method of computing the effectiveness of an insecticide. Journal of Economic Entomology, Oxford, v.18, n.2, p.265-267, 1925. https://doi.org/10.1093/ jee/18.2.265a

BALARDIN, R.S.; SILVA, F.D.L.; DEBONA, D.; CORTE, G.D.; FAVERA, D.D.; TORMEN, N.R. Tratamento de sementes com fungicidas e inseticidas como redutores dos efeitos do estresse hídrico em plantas de soja. Ciência Rural, Santa Maria, v.41, n.7, p. $1120-1126,2011$. http://dx.doi.org/10.1590/ so $103-84782011000700002$
BARROS, E.M.; TORRES, J.B.; RUBERSON, J.R.; OLIVEIRA, M.D. Development of Spodoptera frugiperda on different hosts and damage to reproductive structures in cotton. Entomologia Experimentalis et Applicata, Medford, v.137, n.3, p.237-245, 2010. https://doi.org/10.1111/j.1570-7458.2010.01058.x

BUENO, A.F; SALES, J.F.; BUENO, R.C.O.F.; DA COSTA, R.G.; VIEIRA, S.S. Efeito do tratamento de sementes com inseticidas no controle de pragas iniciais e na qualidade fisiológica das sementes em girassol. Arquivos do Instituto Biológico, São Paulo, v.77, n. 1, p.49-56, 2010. 
BUZZERIO, N.F. Ferramentas para qualidade de sementes no tratamento de sementes profissional. Informativo ABRATES, Londrina, v.20, n.3, p.56, 2010.

CAMERON, R.A.; WILLIAMS, C.J.; PORTILLO, H.E.; MARÇON, P.C.; TEIXEIRA, L.A. Systemic application of chlorantraniliprole to cabbage transplants for control of foliar-feeding lepidopteran pests. Crop Protection, Oxford, v.67, n. 1, p.13-19, 2015. http:// dx.doi.org/10.1016/j.cropro.2014.09.009

CHIESA, A.C.M.; SISMEIRO, M.N.S.; PASINI, A.; ROGGIA, S. Tratamento de sementes para manejo do percevejo-barriga-verde na cultura de soja e milho em sucessão. Pesquisa Agropecuária Brasileira, Brasília, v.51, n.4, p.301-308, 2016 . http://dx.doi.org/10.1590/ so $100-204 \times 2016000400002$

COMPANHIA NACIONAL DE ABASTECIMENTO (CONAB). Acompanhamento da safra brasileira de grãos: Safra 2017/18. Brasília, v.5, n.5, p. 1-140, fev.2018. Available from: <http://www.conab. gov.br/OlalaCMS/uploads/arquivos/18_02_08_17_09_36_ fevereiro_2018.pdf>. Accessed on: Mar. 052018.

CORDOVA, D.; BENNER, E.A; SACHER, M.D.; RAUH, J.J.; SOPA, J.S.; LAHM, G.P.; SELBY, T.P.; STEVENSON, T.M.; FLEXNER, L.; GUTERRIDGE, S.; RHOADES, D.F.; WU, L.; SMITH, R.M.; TAO, Y. Anthranilic diamides: a new class of insecticides with a novel mode of action, ryanodine receptor activation. Pesticide Biochemistry and Physiology, Oxford, v.84, n.3, p.196-214, 2006. https:// doi.org/10.1016/j.pestbp.2005.07.005

CUNHA, R.P.; CORRÊA, M.F.; SCHUCH, L.O.B.; OLIVEIRA, R.C.; ABREU JUNIOR, J.S.; SILVA, J.D.G.; ALMEIDA, T.L. Diferentes tratamentos de sementes sobre o desenvolvimento de plantas de soja. Ciência Rural, Santa Maria, v.45, n.10, p.1761-1767, 2015. http://dx.doi. org/10.1590/0103-8478cr20140742

DEL BEM JUNIOR, L. Análise qualitativa de métodos de tratamento de sementes de soja. 2017. 70f. Dissertação (Mestrado em Proteção de Plantas) - Faculdade de Ciências Agronômicas. Universidade Estadual Paulista, Botucatu, 2017. Available from: https://repositorio.unesp.br/bitstream/ handle/ 1 1449/152644/Del\%2OBem\%2OJunior_I_me_bot. pdf? sequence $=3$ \& isAllowed $=y>$. Accessed on em: Fev. 012018.

DHINGRA, O.D. Importância e perspectivas do tratamento de sementes no Brasil. Revista Brasileira de Sementes, Londrina, v.7, n. 1, p.133-138, 1985.
ESPÍNDOLA, C.J.; CUNHA, R.C.C. A dinâmica geoeconômica recente da cadeia produtiva da soja no Brasil e no mundo. Geo Textos, Salvador, v.11, n.1, p.217-238, 2015.

FERREIRA, D. Sisvar: a computer statistical analysis system. Ciência e Agrotecnologia, Lavras, v.35, n.6, p.1039-1042, 2011. http://dx.doi.org/10.1590/S1413-70542011000600001

HANNIG, G.T.; ZEIGLER, M.; MARÇON. P.G. Feeding cessation effects of chlorantraniliprole, a new anthranilic diamide insecticide, in comparison with several insecticides in distinct chemical classes and mode-of-action groups. Pest Management Science, Medford, v.65, n.9, p.969-974, 2009. https://doi.org/10.1002/ps.1781

KUHAR, T.P.; DOUGHTY, H.; HITCHNER, E.; CASSELL, M. Evaluation of foliar insecticides for the control of Colorado potato beetle in potatoes. Arthropod Management Tests, Oxford, v.34, n. 1, p. 1-9, 2008.

KUSS, C.C.; ROGGIA, R.C.R.K.; BASSO, C.J., OLIVEIRA, M.C.N.; PIAS, O.H.C.; ROGGIA, S. Controle de Helicoverpa armigera (Lepidoptera: Noctuidae) em soja com inseticidas químicos e biológicos. Pesquisa Agropecuária Brasileira, Brasília, v.51, n.5, p.527-536, 2016. http://dx.doi.org/10.1590/SO100-204X2016000500013

LAHM, G.P.; STEVENSON, T.M.; SELBY, T.P.; FREUDENBERGER, J.H.; CORDOVA, D.; FLEXNER, L.; BELLIN, C.A.; DUBAS, C.M.; SMITH, B.K.; HUGHES, K.A.; HOLLINGSHAUS, J.G.; CLARK, C.E.; BENNER, E.A. Rynaxypyr ${ }^{\text {TM }}$ : A new insecticidal anthranilicdiamide that acts as a potent and selective ryanodine receptor activator. Bioorganic จ Medicinal Chemistry Letters, Oxford, v.17, n.22, p.6274-6279, 2007. https://doi.org/10.1016/j.bmcl.2007.09.012

LAI, T.; LI, J.; SU, J. Monitoring of beet armyworm Spodoptera exigua (Lepidoptera: Noctuidae) resistance to chlorantraniliprole in China. Pesticide Biochemistry and Physiology, Oxford, v.101, n.3, p.198-205, 2011.

NAGOSHI, R.N. Can the amount of corn acreage predict fall armyworm (Lepidoptera: Noctuidae) infestation levels in nearby cotton? Journal of Economic Entomology, Oxford, v.102, n.1, p.210-218, 2009. https://doi.org/10.1603/029.102.0130

PEDIGO, L.P. Entomology and pest management. New Jersey: Prentice Hall, 2002. 742p.

TEMPLE, J.H.; POMMIREDDY, P.L.; COOK, D.C.; MARÇON, P.; LEONARD, B.R. Susceptibility of selected lepitopteran pests to Rynaxypyr, a novel insecticide. Journal Cotton Science, Baton Rouge, v.13, n.1, p.23-31, 2009. 